\title{
A crença no Dilúvio: campo e teoria na evolução da paisagem antes da geomorfologia
}

\section{Faith in floods: Field and theory in landscape evolution before geomorphology}

\author{
David R. Montgomery ${ }^{1}$ \\ 1- Departamento de Ciências da Terra e do Espaço. Universidade de Washington, Seattle, EUA. \\ * Tradução feita pelo prof ${ }^{0}$ William Zanete Bertolini (Universidade Federal da Fronteira Sul - Federal University of \\ South Frontier) do original em inglês "Montgomery D.R. 2013. Faith in floods: Field and theory in landscape evolution before
}

\begin{abstract}
Opinions about the origin of topography have long marked the frontier between science and religion. The creation of the world we know is central to religious and secular world views; and until recently the power to shape landscapes lay beyond the reach of mortals, inviting speculation as to a role for divine intervention. For centuries, Christians framed rational inquiry into the origin of topography around theories for how Noah's Flood shaped mountains and carved valleys. Only as geologists learned how to decipher Earth history and read the signature of Earth surface processes did naturalists come to understand the forces that shaped the world. In this sense, the historical roots of geomorphology lie in the tension between faith in theories and the compelling power of field observations, issues that remain relevant to the practice of geomorphology today.
\end{abstract}

\section{Manuscrito:}

Recebido: 25/02/2014

Corrigido: 16/03/2016

Aceito: 21/03/2016

Citation: Montgomery D.R. A crença no Dilúvio: campo e teoria na evolução da paisagem antes da geomorfologia. Terræ Didatica, 13(1):43-61. $<$ http://www.ige.unicamp.br/terraedidatica/>.

Keywords: History of geomorphology, Noah's Flood, field, theory.

\section{Introdução}

As teorias dão o tom de comoas observações são interpretadas. E as observações de campo moldaram as teorias de evolução da paisagem muito antes do desenvolvimento da geomorfologia como disciplina específica (Chorley et al. 1964, Davies 1969, Montgomery 2012). Conquanto os cientistas não mais discutem a respeito da expressão fisiográfica do Dilúvio de Noé, problemas fundamentais surgidos a partir da colocação das teorias acima das observações de campo permanecem pertinentes ainda hoje. O reconhecimento da tensão histórica entre os dados de campo e a teoria ajuda a compreender a natureza complementar desses dois âmbitos. Nesse sentido, uma breve revisão das primeiras ideias acerca da evolução da paisagem e da procura por evidências geomorfológicas de uma inundação global ou do Dilúvio podem forjar o contexto histórico para a compreensão das relações simbióticas entre o trabalho de campo e a teoria.

\section{Os gregos clássicos}

Os filósofos e geógrafos clássicos gregos reconheceram que as paisagens desenvolveram-se durante longos períodos de tempo em resposta a mudanças nos processos erosivos e sob a influência humana. Algumas dessas visões possuem paralelos com as concepções modernas enquanto outras parecem hoje inequivocamente ultrapassadas. Em ambos os casos, as teorias dos filósofos estiveram enraizadas na tentativa de explicar suas observações de campo.

No século VI AC, o filósofo grego Xenófanes encontrou camadas de conchas enterradas nas rochas de Malta e moldes de peixes e focas nas pedreiras de Siracusa (Mayor 2000). Ele concluiu que a evaporação de um vasto mar havia deixado os animais marinhos na lama e que esta, ao secar, converteu-se em rocha. Ele então supôs que a vida foi repetidamente gerada e destruída ao longo de grandes ciclos durante os quais mar e terra mudavam de lugar. 
Por volta da mesma época, o filósofo grego Tales e seus discípulos acreditaram que a água fôsse a mais básica forma da matéria. Consideraram a superfície terrestre como uma crosta originada a partir do endurecimento de um oceano primitivo. Os terremotos tinham origem causada pela mudança desse fino escudo de terra cobrindo vasto oceano subterrâneo. Dois mil anos mais tarde, essa noção ressurgiria no século XVII com as tentativas de explicar a fonte de todas as águas necessárias para produzir uma inundação global sob a insígnia do Dilúvio.

Os gregos clássicos também reconheceram que as paisagens desenvolviam-se ao longo de largos períodos de tempo (Mayor 2000). Em torno de 430 AC, Heródoto observou como a deposição de silte trazido pelo Nilo gradualmente "empurrava" o Egito mar adentro, encalhando as conchas das criaturas marinhas longe da costa. O notável contraste entre o solo aluvial rico e preto do delta do Nilo e o solo das rochas da Síria e da Líbia mostrava como o Nilo ia construindo a riqueza dos solos no seu delta na medida em que avançava na direção do Mediterrâneo.

Aristóteles [384-322 AC] levou essas ideias um passo além e propôs que terras e mares trocavam lentamente de lugar (Mayor 2000). Silte e areia carreados pelos rios gradualmente preenchiam o mar, que eventualmente subia e inundava as terras vizinhas. Os fósseis testemunhavam, portanto, que o mar havia se tornado terra. A ideia de um eterno ciclo no qual terra se transformava em mar e este em terra estava alinhada com a concepção de um mundo sem um começo ou um fim. Aristóteles acreditava que isso acontecia tão lentamente que escapava à observação humana. Civilizações surgiam e antes que pudessem registrar os sinais deste grande ciclo.

\section{De Santo Agostinho a Leonardo}

Os primeiros conceitos cristãos acerca da evolução da paisagem foram centrados nas histórias da Criação e do Dilúvio, os únicos eventos mencionados na Bíblia que poderiam dar forma às paisagens. Alguns exegetas discutiram que o livro do Gênesis claramente indicava que as montanhas já existiam antes da Criação. Prova disso seriam os trechos nos quais se afirma que o Dilúvio de Noé cobriu todas as colinas sob o céu. Eles interpretaram a história de modo que as montanhas não poderiam ter se originado durante o Dilúvio e, portanto, devem ter surgido durante a Criação - o único evento significativo para a história da Terra mencionado na Bíblia, uma fonte segura e verdadeira, já que continha as palavras do Criador. Outros exegetas questionaram-se porque as montanhas não haviam sido mencionadas antes se elas já existiam antes do Dilúvio. Já outros sugeriram que a topografia da superfície terrestre como a conhecemos hoje teve sua origem como resultado do Dilúvio. Apesar das discordâncias sobre a origem da topografia terrestre, os estudiosos dos textos bíblicos geralmente concordavam que a superfície da Terra vinha sendo lentamente erodida desde o Dilúvio. A evolução da paisagem foi relacionada à Criação Divina e subsequentemente remodelada por meio do Dilúvio. As diferentes opiniões centravam-se sobre como a grande inundação ocorreu, de onde vieram todas essas águas e para onde foram após a inundação global.

Já nos primórdios do cristianismo, grandes teólogos pensaram em como o mundo natural poderia revelar a história da Terra (e.g., Agostinho 1982). No século IV depois de Cristo, Santo Agostinho chamava atenção para a falta de razão na interpretação dos textos bíblicos. Ele se perguntava se as pessoas deveriam aceitar uma religião que ensinava coisas em discordância com o que elas podiam aprender a partir da razão e das suas próprias experiências. Agostinho defendia que a razão deveria guiar a busca pelo conhecimento do mundo natural e de como interpretar a origem do mundo e da superfície terrestre.

\footnotetext{
É uma trabalhosa e difícil tarefa para os poderes do entendimento humano compreender claramente os significados do Criador sobre a matéria daqueles seis dias.... Se formos capazes de avançar na compreensão do significado daqueles dias, não devemos nos precipitar em mal fundadas opiniões, como se nenhuma outra interpretação plausível e razóavel pudesse ser oferecida (Agostinho 1982 p.103, 135).
}

Agostinho considerou os fósseis presentes nas rochas das montanhas como uma prova persuasiva do Dilúvio. Ele também teorizou que a topografia plana anterior a esta inundação global ajudava a entender como o Dilúvio submergiu o mundo inteiro.

É bem provável que nos primeiros dias da Terra muitas áreas, embora nem todas, fossem planas, de modo a possibilitarem uma larga dispersão e expansão das águas (Nicolson 1997, p.90). 
Dado que Agostinho tenha baseado seus argumentos na razão, parece improvável que ele rejeitasse a moderna geologia em favor de uma leitura literal do Dilúvio e da superfície terrestre como daí resultante.

Os contemporâneos de Agostinho, como Procópio de Gaza [cerca de 465-538 DC], também consideraram os fósseis como evidências inequívocas de uma inundação sobre todas as terras do mundo:

Pode ser evidenciado de muitas outras maneiras que uma inundação universal atingiu a terra ... . Até hoje nos altos topos montanhosos restos marinhos podem ser encontrados... (Young 1995, p.26)

A teoria aceita de uma inundação global, na figura do Dilúvio bíblico, produziu o que seria uma explicação razoável para os problemas relativos aos fósseis e à formação da superfície terrestre.

O poder da erosão em modelar a superfície foi reconhecido por alguns observadores anteriores, mas a pouca idade que se julgava possuir o planeta era incondizente com a quantidade de trabalho demandada por esses processos em operação atualmente para originar e moldar a topografia do planeta. Por exemplo, no século VII depois de Cristo, São Beda (o Venerável Beda) afirmou que o Dilúvio aniquilou a Terra original e remodelou sua topografia (Nicolson 1997).

A Terra tomou uma aparência diferente quando as águas recuaram. Acreditava-se que algumas montanhas e vales foram originalmente criados mas não em número e extensão com os quais são agora encontrados na superfície da Terra. Poderia ser possível negar isto se não fosse o fato de que estamos aptos a observar as mudanças a cada ano sobre a terra pela ação da água. Por isso é mais fácil acreditar que tais mudanças aconteceram naquele tempo, quando a ação das águas sobre a terra foi mais potente e de longa duração (Nicolson 1997, p.91).

São Beda aplicou o raciocínio geomorfológico para deduzir que se os rios atuais eram capazes de gradualmente modificar a topografia, então um desastre cataclísmico como o Dilúvio poderia rapidamente ter escavado vales e dado origem a montanhas.

O estudioso islâmico Avicena [980-1037 DC], também conhecido como Ibn-Sina, afirmou que as montanhas poderiam se formar tanto por soerguimentos a partir de terremotos ou por erosão, proporcionada pelas águas correntes ao longo de muito tempo. Avicena escreveu sobre as camadas rochosas da sua terra natal, o Uzbequistão, notando que as sucessivas camadas haviam sido depositadas gradualmente uma em cima da outra. Na primeira tradução do seu texto para o latim esta passagem foi perdida, embora não se tenha clareza se o texto foi censurado ou foi traduzido a partir de uma cópia incompleta. O livro de Avicena foi inicialmente considerado uma obra perdida de Aristóteles, cuja crença na eternidade do mundo foi considerada como herética, e que, de fato, tornou difícil a aceitação da ideia de que as rochas seriam formadas lentamente, umas sobre as outras, a partir das camadas presentes no fundo dos mares.

As universidades medievais não ofereceram condições nem de proteção, nem de encorajamento ao pensamento criativo. Elas não foram fundadas para a descoberta de coisas novas, mas para preservar o conhecimento antigo. Acadêmicos respeitáveis absorveram os conhecimentos de Aristóteles e seus contemporâneos. O conhecimento do mundo se tornou tão centrado na compilação de trechos dos textos antigos que o alquimista dinamarquês Petrus Severinus advertiu seus estudantes a saírem e verem com seus próprios olhos as coisas do mundo.

Queimem os seus livros e comprem bons calçados, subam as montanhas, procurem nos vales ... e profundezas da terra ... Observem e experimentem sem cessar, porque só assim vocês chegarão ao verdadeiro conhecimento da natureza das coisas (Cutler 2003, p.17).

À medida que o conhecimento do mundo natural crescia, tornou-se intrigantemente desafiadora a ideia sobre a origem das águas que recobriram o mundo durante o Dilúvio.

Leonardo da Vinci [1452-1519 DC] notou algo entre as conchas de criaturas marinhas encontradas nas rochas próximas à sua casa em Vinci que o fez duvidar que tivesse sido o Dilúvio a deixá-las ali, incrustradas nas rochas (Mather \& Mason 1970). Algumas conchas pareciam ter sido fixadas como se tivessem sido enterradas vivas. Outras estavam fragmentadas e dispersas em depósitos semelhantes aos que se encontram nas praias de hoje. Até mesmo marcas de vermes marinhos foram preservadas 
nas camadas rochosas. Como, ele se questionava, poderiam esses vermes ter rastejado no meio de uma inundação catastrófica como o Dilúvio?

Observando como o fluxo d'água movia os sedimentos, Leonardo concluiu que uma grande inundação não poderia ter carregado conchas antigas para o topo das montanhas por uma simples razão: fósseis e outros objetos mais pesados que a água afundam. O Dilúvio não poderia ter depositado esses fósseis nas montanhas porque tudo aquilo que é mais pesado que a água não flutua em sua superfície (Mather \& Mason 1970, p.5). Ele também reconheceu que a água no fundo de uma onda afasta-se da linha da costa; assim os fósseis deveriam ser movidos para dentro do mar e não empurrados para os topos das montanhas. Em suas anotações, Leonardo desfez-se da ideia que o Dilúvio havia depositado tais criaturas marinhas muito acima do nível do mar. Isto não era condizente com o modo com que o mundo funcionava. A história da Terra era mais complicada do que se podia depreender de uma simples leitura do livro do Gênesis.

Leonardo pensava que as camadas das rochas sedimentares formaram-se como lama e gradualmente endureceram-se no fundo de antigos mares. As conchas fósseis preservadas nas rochas dos morros em torno de Florença foram depositadas quando o mar se encontrava acima do nível atual. Ao não reconhecer nenhuma evidência de uma inundação catastrófica, ele concluiu, por observações na bacia do rio Arno, que os rios escavavam os vales por onde corriam. Leonardo também notou como os rios eram muito mais turvos onde corriam por áreas povoadas.

Leonardo não esteve sozinho ao questionar se o Dilúvio teria esculpido a superfície terrestre e sobre o trabalho da erosão em modelar a paisagem. O estudioso germânico George Bauer [1494-1555 DC], mais conhecido como George Agricola (o pai da mineralogia), escreveu sobre a ação dos rios e canais de entalhar a paisagem (Mather \& Mason 1970). Ele entendeu as montanhas como resultantes do trabalho erosivo.

Agora nós claramente podemos ver que uma grande abundância de água produz montanhas, uma vez que as torrentes lavam a superfície da terra e os sedimentos, carregam-nos e então desmontam as rochas. Em alguns anos elas escavam as planícies ou vertentes com uma considerável profundidade; isto pode ser observado nas regiões montanhosas até mesmo pelos mais inaptos observadores. Por um processo similar o ímpeto das águas aniquila e aplaina montanhas e colinas (Agricola 1912, p.595).

Bem familiarizado com os terrenos montanhosos ao longo das suas experiências como engenheiro de minas, Agricola argumentou que qualquer um poderia ver como o vento, a chuva e as inundações gradualmente moldavam a paisagem.

Todos estes processos variados e maravilhosos, pelos quais a água destroi e constroi, intensivamente vão alterando a aparência da superfície terrestre e têm estado em operação desde os mais remotos tempos, quando nem mesmo a memória humana poderia recordar o seu início (Nicolson 1997, p.155).

Antecipando o conceito de tempo geológico, Agricola reconheceu que as mudanças geomorfológicas aconteciam tão lentamente que impediam a visão humana de contemplar o criativo trabalho da natureza.

Da Vinci e Agricola podem não ter sido os únicos a endossar o poder erosivo de modelar a paisagem mas eles certamente fizeram parte de uma minoria. O Dilúvio permaneceu sendo a teoria dominante da evolução da superfície terrestre ao longo do século XVII.

\section{Os estudiosos do século XVII}

No início do século XVII, duas escolas de pensamento estruturaram as visões sobre a natureza do Dilúvio. Uma imaginou uma violenta correnteza que varreu o mundo, quebrando a crosta terrestre e escavando a superfície. A outra descreveu a grande enchente bíblica como algo que suavemente foi afogando toda a vida mas deixando a superfície terrestre incólume.

Encarcerado por mais de uma década na Espanha, Sir Walter Raleigh [c.1552-1618] escreveu sua História do Mundo desde a Criação enquanto esperava sua sentença (Raleigh 1628). Raleigh organizou os argumentos do relato bíblico em concordância com uma inundação global, tendo em conta que um profeta nativo americano disse-lhe que uma grande inundação havia coberto suas terras há muitos anos. Para explicar de onde veio toda essa água, ele argumentou que a atmosfera se condensou totalmente e então se combinou com a água que transbordou do interior da Terra para arrebatar todas as sociedades corrompidas. A tentativa de Raleigh de explicar o Dilúvio influenciou 
gerações de filósofos da Natureza e o modo como se entendia a origem da superfície terrestre.

Mas o próprio Raleigh rejeitou a ideia de uma inundação violenta. Ele era a favor de uma inundação gradual e tranquila. Como, ele se perguntava, poderia o Dilúvio ter remodelado a topografia da Terra se Moisés havia descrito o Jardim do Éden em termos da moderna geografia? E a folha de oliveira, que a pomba trouxe de volta à arca, não era indício de que a inundação não tinha destruído toda a vegetação? Então, como o Dilúvio poderia ter desmantelado a superfície e, sozinho, ter escavado vales profundos nas altas montanhas? Raleigh descartou a ideia de uma inundação local porque pensava que existia água suficiente para cobrir até mesmo as montanhas mais altas. Com o raio da Terra mais de cem vezes maior que a altitude das mais altas montanhas, o afogamento do mundo simplesmente requeria um extravasamento das fontes das profundezas da Terra. De onde Raleigh tirou essa ideia?

Aristóteles ensinava que reservatórios subterrâneos eram responsáveis por suprir as águas dos rios por meio de um complexo sistema hidráulico que atuava como uma espécie de pavio gigante imerso nos oceanos. Raleigh acreditou na existência de imensos lagos subterrâneos que teriam sido a fonte das águas do Dilúvio. A existência dos grandes reservatórios, conhecidos como hydrophylacia, foi arquitetada em função da observação de que os rios continuam fluindo após o término das chuvas. De onde mais poderia vir esse fluxo incessante senão de alguma fonte subterrânea que alimentava as fontes das montanhas?

Muitos pensadores da natureza seguiram essas especulações teóricas desvinculadas de evidências e observações de campo. Hoje, suas teorias fantásticas nos servem de alerta para não tentarmos adequar os dados e interpretações de campo às teorias, mas sim para contrapor esses dados e teorias com as observações de campo. Descartes propôs que as montanhas formaram-se quando a superfície primitiva do planeta colapsou-se em um mar interior posicionado entre a crosta exterior e uma crosta interna metálica. Teorias altamente imaginativas proliferaram para explicar a origem da topografia terrestre. Muitos concordavam que o Dilúvio era um fator geomorfológico chave nesse contexto. Aliás, o primeiro uso da palavra geologia em inglês foi no título de um livro do século XVII sobre o Dilúvio (Warren 1690).

O clérigo de Cambridge Thomas Burnet escre- veu sua Sagrada Teoria da Terra (1684), baseando-se no modelo de Descartes, para explicar as evidências de uma grande catástrofe que havia deformado e caoticamente disposto as rochas dos Alpes. Ele interpretou as camadas discordantes da topografia de morros como as ruínas do outrora perfeito Jardim do Éden. Burnet propôs que na Criação Deus ordenou que os elementos se ordenassem por densidade, os mais pesados afundaram para formar o centro e o núcleo da Terra e os mais leves coalesceram em uma crosta fina acima de um oceano subterrâneo (Fig. 1). O calor do Sol gradualmente esquentou e quebrou a crosta exterior que se colapsou no abismo das águas profundas desencadeando o Dilúvio e deixando como resultados as montanhas e os rios que as drenam. Burnet considerou as estações como mais uma evidência dessa catástrofe, argumentando que antes do Dilúvio a Terra girava segundo um eixo vertical, sem inclinação, e que isso mantinha a Terra em um perpétuo equinócio, com um clima ameno e agradável a tudo e a todos. A força do Dilúvio bíblico alterou o eixo de rotação do planeta, criando as diferentes estações.

Ele inferiu que inundações catastróficas afetaram não somente a Terra, mas também outros planetas. Os anéis de Saturno eram os resquícios equatoriais de uma crosta exterior que se quebrou, deixando pra trás uma estreita tira intacta. Somente Júpiter permaneceu com a sua superfície lisa original. Sua teoria de uma inundação catastrófica forjou o modo como ele encarou as evidências neste e em outros mundos.

No fim do século XVII, o professor John Woodward, do Colégio Médico de Gresham, baseado na Sagrada Teoria da Terra de Burnet, propôs um mecanismo pelo qual o Dilúvio havia imobilizado os fósseis dentro das rochas e moldado a superfície no seu Ensaio para uma história natural da Terra (1723/1695). Woodward ajustou a ideia de Burnet de uma separação gravitacional dos elementos durante a formação da crosta primordial e aplicou-a aos materiais trazidos das profundezas pelo Dilúvio. Ele propôs que Deus, ao desencadear o Dilúvio, temporariamente suspendeu a força da gravidade, o que fez com que o mundo se desmantelasse. Quando a gravidade voltou a agir, tudo se acomodou de acordo com a densidade, formando as camadas rochosas. A topografia da superfície originou-se de colapsos localizados nesta nova e irregular crosta planetária.

Woodward pensou que os fósseis foram preservados dentro das rochas em função das fibras 
orgânicas que permitiam que os tecidos animais e vegetais se mantivessem unidos. Ele rejeitou a ideia de que a descoberta de fósseis de espécies desconhecidas fosse um problema, seguro de que exemplares dessas espécies seriam encontrados em alguma região remota ou nas profundezas dos mares. Compilando as considerações de correspondentes ao redor do mundo sobre fósseis, Woodward concluiu que fósseis e rochas haviam sido misturados por alguma grande catástrofe que afetou o mundo bem além da Bretanha. Como, ele se questionava, alguém poderia explicar tais observações de campo a não ser por meio de uma inundação que cobriu toda a Terra?

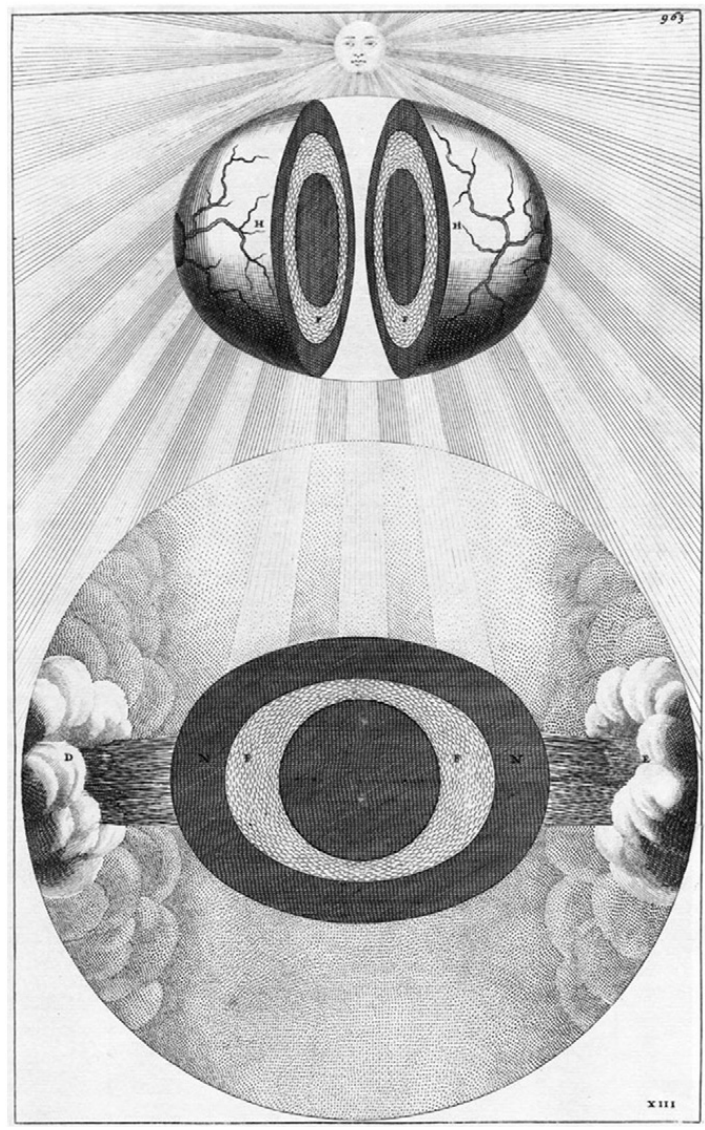

Figura 1. Ilustração relacionada à teoria de Thomas Burnet para explicar o Dilúvio na Terra, representada como uma esfera com uma crosta externa solidificada acima de uma camada oceânica interna. Quando o calor do Sol quebrou esta crosta externa, ela afundou na camada oceânica subjacente e as águas emergiram, inundando todo mundo. Fonte: Goeree (1690)

Problemas com as ideias elegantemente simples sobre o porquê tudo se encontrava como estava por causa do Dilúvio tornaram-se óbvios quando os naturalistas começaram a investigar a estratigrafia das suas regiões. Em uma descrição sobre uma mina de carvão em Staffordshire apresentada no Philosophical Transactions of the Royal Society of London, Fettiplace Beller (1710) incluiu uma tabela com as densidades específicas dos estratos como evidência refutadora do modelo de Woodward. No campo, as coisas mais densas nem sempre se encontram debaixo das mais leves. As próprias rochas rejeitam o modelo de Woodward de dissolução do globo pelo Dilúvio.

Steno [1638-1686], o bispo católico renomado como o grande pai da geologia, desenvolveu seus famosos princípios para interpretrar as evidências geológicas em campo (e.g., Cutler 2003). Quando foi atraído para os problemas geológicos após averiguar a origem orgânica dos fósseis, Steno começou a observar a relação existente entre a geologia e a topografia em suas caminhadas pelas montanhas da Toscana à procura de fósseis. Ele deu início a um novo caminho para a geologia e sua experiência em anatomia foi fundamental para isso. A curiosidade de Steno foi incentivada pelo Grão Duque da Toscana, Ferdinando II, que mandou abrir pedreiras e minas para que Steno pudesse explorar o que havia no subsolo. O que Steno encontrou nesses lugares o tornou cada vez mais convencido de que os fósseis encontrados nas rochas haviam sido ali aprisionados em um ambiente de mar antigo.

Steno mapeou a história contida nas rochas de acordo com seu entendimento do relato bíblico. Para explicar a história geológica da Toscana ele invocou dois ciclos compostos pelos processos de inundação, drenagem e desmoronamento da superfície (Fig. 2). No primeiro estágio de cada ciclo, os sedimentos deixados pela água compõem uma sucessão de camadas horizontais. Em seguida, após o recuo das águas os sedimentos se litificam e a ação da água ou do fogo no interior da Terra esculpe as grandes cavernas subterrâneas. O colapso das camadas sobrejacentes sobre essas cavernas produz a inclinação dos estratos, vistos à superfície. Sob os efeitos de um novo ciclo, os vales são preenchidos com sedimentos. Então, a paisagem que conhecemos hoje formada outrora pelo recuo das águas, leva a uma nova sequência de solapamento e colapso.

A maior novidade trazida por Steno foi a compreensão de que o arranjo das camadas atuais que compõem a superfície pode ser usado para ler sua história passada. A chave para a leitura da geologia da Toscana foi a simples ideia de que as rochas mais jovens assentam-se sobre as mais antigas. 
Steno adotou essa ideia, que permaneceu como a base para a geologia moderna e ajudou a explicar como o Dilúvio moldou a paisagem italiana.

O Dilúvio permaneceu como a teoria central sobre a evolução da superfície terrestre até o século XVIII. Afinal de contas, que teoria melhor poderia explicar a presença de criaturas marinhas presas nas rochas encontradas nas altas montanhas, ou dos fósseis dos pecadores afogados pelo Dilúvio (Fig. 3)? O começo das mudanças ocorreu com as investigações estratigráficas na Europa que revelaram uma história muito mais longa e complicada do que até então a imaginada pelo mecanismo diluviano.

\section{À procura de um tempo suficientemente longo}

Em torno da mesma época que Burnet e Woodward desenvolveram suas teorias sobre a Terra baseadas no Dilúvio, o diplomata francês Benoît de Maillet [1656-1738] trabalhou no Oriente Médio e Mediterrâneo como cônsul francês no Egito (de Maillet 1797). Suas observações das rochas da região convenceram-no de que elas haviam sido depositadas ali durante um gradual abaixamento dos oceanos por muitos milhões de anos. Ele imaginou que um único e grande oceano gradualmente foi se encolhendo e deixando encalhadas nos sedimentos marinhos as conchas no alto das montanhas.

Escrito com certa aproximação às lendas egípcias, o livro de Benoît de Maillet (1797) propôs que o mundo tivesse cerca de dois bilhões de anos de idade - tão velho quanto o tempo necessário para que o grande oceano que cobria a Terra em seus primórdios fosse esvaziado em função de profundas rachaduras e fissuras na crosta. Este foi o limite de tempo permitido pela cronologia bíblica e que não atribuía nenhum papel geológico ao Dilúvio. De Maillet afirmou também que os seres humanos surgiram das sereias e dos tritões. Para os contemporâneos, suas afirmações extravagantes de uma Terra inimaginável parecem apenas mais uma ideia bizarra. Consciente de que sua teoria se provaria controversa, Maillet esquivou-se de ser censurado ao atribuir seus argumentos a um suposto filósofo indiano chamado Telliamed (de Maillet soletrado de trás para frente) - e retardou a publicação de sua obra até uma década antes da sua morte.

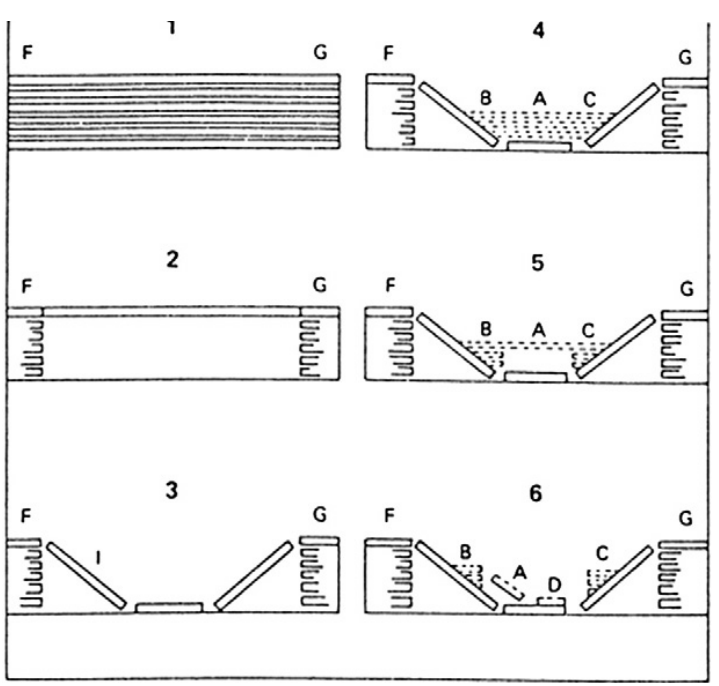

Figura 2. Ilustração do modelo de Steno em seis estágios para explicação da paisagem nos arredores de Florença: (1) rochas sedimentares afossilíferas precipitadas em um oceano universal; (2) fogo ou água escavaram cavernas; (3) colapso dos continentes, inundação dos vales recém-formados (pelo Dilúvio); (4) camadas de rochas sedimentares contendo fósseis depositados pela regressão das águas diluvianas; (5) novo solapamento das rochas mais jovens criando vales que acabam por (6) dar origem a novos colapsos que originaram a topografia atual

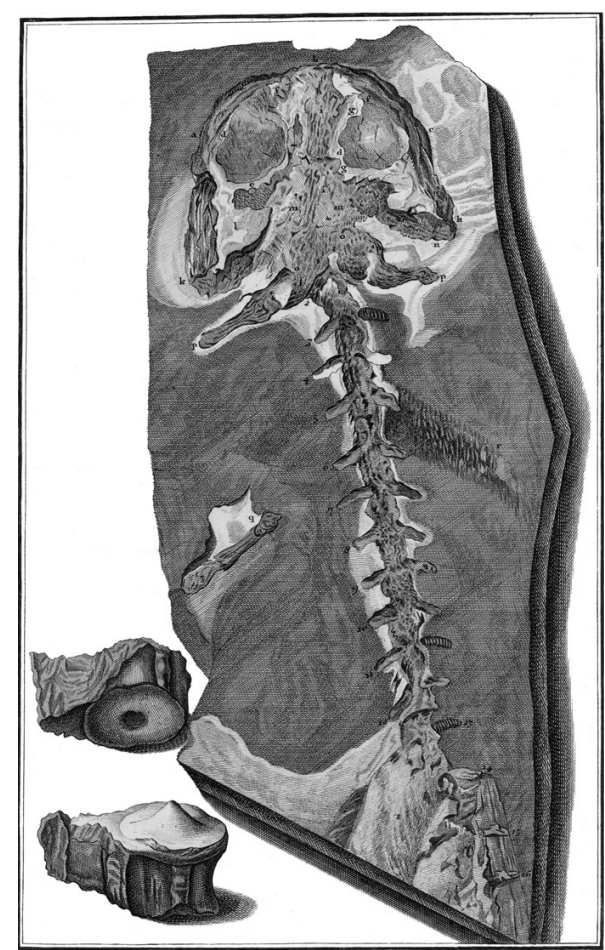

Figura 3. Homo Diluvii Testis (O homem que testemunhou o Dilúvio), fóssil de anfíbio gigante que, inicialmente, pensava-se tratar de um pecador afogado pelo Dilúvio. Fonte: Scheuchzer (1731) 
George-Louis Leclerc, o Conde de Buffon [1707-1788], também diretor do Jardim Botânico Real [hoje Museu de História Natural de Paris], transformou a ideia de Benoît de Maillet sobre a descida do nível dos oceanos em uma grande teoria para explicar a história biológica e geológica como decorrente de um planeta que gradualmente foi se resfriando a partir de uma enorme bola de material em fusão. No primeiro volume dos seus massivos 34 volumes da Histoire Naturelle (História Natural, Buffon 1749), Buffon argumentou que o nosso planeta se formou quando um cometa se chocou com uma parte do Sol. Após essa colisão, a matéria desprendida do Sol se resfriou em um satélite rochoso. Posteriormente, o nível do oceano primitivo diminuiu de modo a deixar expostos os continentes.

Dois anos depois da publicação da sua História Natural, a faculdade de teologia de Sorbonne enviou a Buffon uma carta identificando em seus argumentos mais de uma dúzia de ideias heréticas, incluindo a de que as correntes das águas do oceano primitivo modelaram as montanhas e os vales; a de que a superfície terrestre era resultado mais da erosão do que do poder divino por meio do Dilúvio; e a de que em um tempo futuro as montanhas poderiam ser erodidas ao nível do mar, reduzindo a superfície terrestre a uma grande planura. Forçado a escolher entre a retratação ou em manter seu prestígio, Buffon renunciou aos seus argumentos, respeitando a ideia da formação da Terra como descrita na narrativa bíblica (White 1910, p.215).

Buffon, no entanto, manteve suas experiências sobre o tempo de resfriamento de metais fundidos e determinou que o primeiro dia da Criação teria durado mais de 25.000 anos, levando-se em conta o tempo de resfriamento a ponto de permitir que a água pudesse se acumular na superfície do planeta. Baseado em taxas pluviométricas, ele calculou que o segundo dia bíblico da Criação deve ter durado 10.000 anos para ter dado origem aos primeiros oceanos por meio das águas atmosféricas. Após décadas, quando Buffon estimou a idade da Terra em cerca de 75.000 anos (Buffon 1778), a Igreja permaneceu em silêncio, reclusa em suas próprias controvérsias sobre como interpretar o Gênesis.

Buffon desenvolveu o argumento de que aos dias da Criação correspondiam eras geológicas (Buffon 1778). Cautelosamente abstendo-se de publicar uma idade estimada em milhões de anos, ele argumentou que o planeta gradualmente foi se resfriando até formar o mundo como o conhe- cemos hoje. A primeira das suas grandes épocas foi a que deu origem à formação da Terra e dos outros planetas. Durante a segunda época, o interior rochoso da Terra se consolidou e liberou as substâncias voláteis responsáveis pela origem da atmosfera. Durante a terceira época, há cerca de 35.000 anos após a formação do planeta, a água cobriu os continentes deixando para trás os mármores, as rochas estratificadas, o carvão e os fósseis marinhos. As correntes dos fundos desse grande oceano primordial esculpiram a moderna topografia. Os vulcões tornaram-se ativos na quarta época. Os mamutes e outros animais tropicais habitaram a Sibéria durante a quinta época, quando as regiões setentrionais do globo experimentaram um clima mais ameno. Na sexta época, os continentes se separaram uns dos outros e a crosta subsidiu para formar as bacias oceânicas. Finalmente, a chegada da humanidade aconteceu na época atual, iniciada há cerca de 6.000 anos atrás.

Os estudos de campo do século XVIII nos Alpes europeus permitiram documentar uma ordem regular das formações geológicas europeias e fizeram cair por terra a ideia de que a superfície terrestre havia sido formada em um evento singular e catastrófico. Em 1721, o professor Antonio Vallisnieri da Universidade de Pádua concluiu que um tempo muito mais longo que o do Dilúvio foi necessário para originar as inumeráveis camadas de rochas marinhas nos Alpes (Fig. 4). As incontáveis camadas rochosas não poderiam ter se depositado ao final de um único grande evento de inundação da Terra. Como um simples evento poderia produzir centenas de camadas com características de composição e granulometria diferenciadas em cada um dos dias do Dilúvio? Esta era a dúvida de Vallisnieri. Não houve tempo suficiente para que todas aquelas camadas rochosas se depositassem em um único ano.

O padre e naturalista católico Anton-Lazarro Moro seguiu as descrições de Nicolau Steno das montanhas, assim como a sua classificação em rochas primárias ou secundárias de acordo com a natureza maciça ou estratificada das rochas. Ele atribuiu à formação de rochas duras, cristalinas e não estratificadas, como o granito e o basalto, ao calor interno do planeta, enquanto as rochas estratificadas (como o arenito e o carvão) foram consideradas originadas do abaixamento do nível do mar e do retrabalhamento erosivo das rochas primárias.

O professor veneziano Giovanni Arduino expandiu a classificação geológica das camadas 
rochosas e incluiu quatro categorias (Bates 1950). O estrato primário no fundo do pacote geológico teria sido aquele que foi dobrado e não continha fósseis. O estrato secundário sobrejacente foi também dobrado mas continha fósseis. O estrato terciário foi formado pelo desgaste das rochas que continham fósseis e que deram origem aos cascalhos, areias e argilas derivadas das rochas primárias e secundárias subjacentes. Assentado no topo desses três estratos existia um quarto nível (ou estrato quaternário) de material superficial recentemente erodido das montanhas a partir do escoamento superficial, como era o caso, por exemplo, das areias e cascalhos do vale do rio Pó. Arduino afirmou que essas quatro divisões representaram distintas épocas na história da Terra. A curto prazo, outros acreditaram que a classificação de Moro também serviria para outras cadeias montanhosas, como os Apeninos e o Cáucaso. A história geológica se mostrava mais complicada do que se pensava, ao ser explicada por um único grande evento, não importava quão grande fosse a catástrofe. As evidências de campo começaram a remodelar as visões da história terrestre e as relações entre a superfície e as rochas subjacentes.

Uma das últimas tentativas sérias de explicar a história da Terra e a formação da sua superfície pelo Dilúvio foi do professor Alexander Catcott [17251779], em seu Tratado sobre o Dilúvio (1761). Catcott tinha o costume de investigar a geologia no sudeste da Inglaterra onde as descontinuidades dos estratos expostos nas colinas daquela região permitiram-lhe supor que algo fora responsável pela remoção de uma grande quantidade de massa rochosa ali existente.

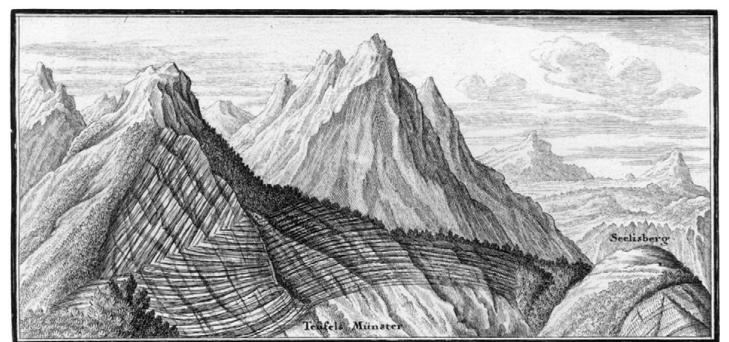

Figura 4. Ilustração das camadas rochosas e estruturas dos Alpes, de Scheuchzer (1731)

Se uma pessoa fosse capaz de ver com toda clareza as camadas rochosas de um lado e de outro de um vale montanhoso e as comparasse ele perceberia que o espaço entre cada um dos lados do vale apresenta uma continuidade dos estratos rochosos (Catcott 1761, p.163).
Catcott reconheceu que a superfície terrestre foi escavada a partir de formações contínuas e que estas não resultavam do colapso da crosta, como Burnet (1684) e Woodward (1723/1695) haviam teorizado.

O que havia removido todas as camadas que outrora existiram ali? Terremotos não pareciam ser os agentes mais adequados desse processo. A erosão sim, por meio dos impetuosos fluxos d'água. Catcott viu, assim, as impressões de uma grande enchente bíblica como eloquentemente escritas nas formas do terreno.

Citando exemplos de histórias de grandes inundações da Grécia, de Roma e dos nativos americanos, Catcott apresentou-os como evidências de uma inundação global. Assim ele misturou a ideia de Burnet acerca do Dilúvio a partir do abismo subterrâneo com a ideia de Woodward de que as rochas que continham fósseis originaram-se fora das enchentes. Catcott propôs que a Terra primitiva consistia de um espaço interior vazio e preenchido com ar sob pressão, como um balão gigante. A crosta externa foi cercada por água de ambos os lados em função desse ar pressurizado. Quando o calor do Sol fez com que o ar do interior do planeta se expandisse a crosta se quebrou, a água subterrânea emergiu preenchendo o espaço vazio e escavou vales na superfície primitivamente lisa do planeta. Então, quando chegou o tempo, tudo que Deus teve que fazer foi empurrar o ar remanescente de novo para o interior do planeta a fim de abrir caminho para as águas do Dilúvio.

Como Woodward, Catcott entendeu o Dilúvio como uma força de dissolução da superfície terrestre. Ele defendeu a ideia de que o recuo das águas escavou vales nas camadas de sedimentos ainda não consolidados. A teoria de Catcott apontou para a diferença entre as rochas primárias estratificadas e quebradas e as rochas mais jovens, portadoras de fósseis, que ele atribuiu a uma inundação global.

Para testar sua teoria, Catcott tomou um grande recipiente de vidro com buracos nos lados. Após tampar os buracos, ele preencheu o recipiente com água e sequencialmente adicionou rocha pulverizada, carvão, argila e gipso, deixando cada um desses materiais se depositar, formando uma sucessão de camadas. Quando retirou os tampões do recipiente, rapidamente a água moldou uma paisagem em miniatura com diminutas montanhas, vales e planos. Ironicamente, o experimento de Catcott apresentou uma abordagem e provas científicas para ideias que logo mais não se sustentariam. 
Como um naturalista que empreendeu cuidadosas observações das relações entre as formas superficiais da paisagem, seus depósitos, fósseis e estratos que os continham, Catcott permaneceu inquieto e curioso com as rochas que apresentavam dentro de si seixos que eram constituídos de calcário ou xisto. Uma inundação global não poderia explicar rochas semelhantes contidas umas dentro das outras. Como os sedimentos macios depositados pelo Dilúvio poderiam ser solidificados, soerguidos, arredondados em seixos e serem incorporados em outras rochas durante um único evento? Se Catcott tivesse reconhecido isso como um sinal de duas épocas, uma de construção de montanhas e outra do seu arrasamento, ele teria sido o pioneiro na descoberta do tempo geológico e considerado um influente cientista. Ao invés disso, suas ideias constelaram-se em uma história arriscada que alia muita fé junto a uma teoria mal concebida.

O fazendeiro escocês James Hutton [17261797] desenvolveu a ideia de que as paisagens são modeladas pelos processos erosivos atualmente observáveis. Baseado na observação de como suas terras eram lavadas e desgastadas pela água, Hutton propôs que o material erodido dos continentes gradativamente ia se empilhando no fundo do mar até que essa pilha se tornou tão espessa ao ponto de fundir sua própria base, fazendo com que as camadas oriundas dessa rocha voltassem à superfície. Sua descoberta de uma inconformidade angular entre dois arenitos - um Devoniano e outro Siluriano evidenciou que o tempo geológico consistia de um tempo suficientemente longo durante o qual duas montanhas haviam sido soerguidas, erodidas e, por fim, escondido suas raízes abaixo da paisagem atual (Fig. 5). Sua nova teoria não obteve popularidade imediatamente porque ia contra a percepção dominante de que a história da Terra era curta e que o relevo havia sido esculpido por grandes catástrofes ou correntes abaixo de um oceano primitivo. As ideias de Hutton somente se disseminaram décadas após sua morte, depois de seu amigo e colega John Playfair tê-las elaborado melhor e as popularizado. Por sua vez, as ideias de Hutton difundidas por Playfair influenciaram grandemente Charles Lyell que consolidou a visão de que os processos observáveis atualmente são responsáveis por modelar as formas de relevo.

O geólogo suíço Jean-André de Luc [17271817] foi um expoente da reinterpretação do livro do Gênesis no sentido de acomodar junto à narrativa bíblica um lapso de tempo que vinha se tornando cada vez maior para a história da Terra. Suas Cartas sobre a história física da Terra [Letters on the Physical History of the Earth] (De Luc 1831-1798) endossaram a ideia de que a história da Terra envolveu seis épocas, correspondentes aos seis dias da criação. Convencido de que as rochas e as formas da superfície registraram a história do planeta, de Luc escalou montanhas e desceu a profundas minas na Europa e baseou suas opiniões em descrições detalhadas de estratos rochosos, após cuidadosamente ter sumarizado e discutido os trabalhos de seus antecessores. De Luc viu que a geologia da Europa demonstrava a conformidade dos monumentos geológicos com o sublime trabalho que aconteceu durante os Seis Dias, registrados pelo seu inspirado Autor (Cohn 1996, p.110). De Luc acreditou que havia um paralelismo muito grande entre o livro do Gênesis e as rochas se estas fossem interpretadas ao longo de seis eras e não de seis dias. Ele entendeu que os seis dias da Criação foram de uma duração extremamente grande e que os fósseis e rochas aí gerados corresponderiam às primeiras épocas da história da Terra. Os seres humanos somente apareceram na época recente aquela que terminou com o Dilúvio.

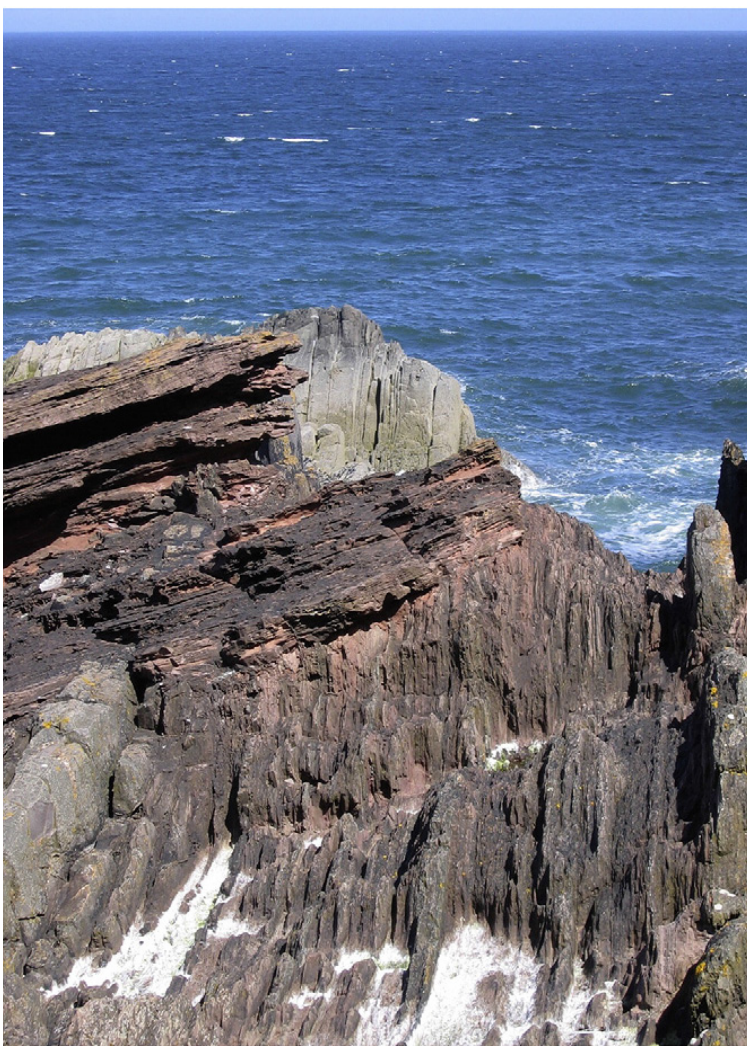

Figura 5. Siccar Point - Escócia - onde James Hutton reconheceu o imenso lapso temporal representado pela inconformidade entre os arenitos Devoniano e Siluriano. Fotografia de David R. Montgomery 
De Luc entendeu que os continentes foram muito maiores antes do Dilúvio e que as erupções vulcânicas abaixo do mar e a lenta infiltração da água dentro da crosta escavaram grandes cavernas na Terra primitiva. Embora Thomas Burnet tenha teorizado um século antes, De Luc acreditou que o colapso de grandes cavidades no interior da crosta e no fundo dos oceanos afogou grande quantidade de pessoas. A falta de fósseis humanos foi devida ao afundamento dos ossos no fundo do novo leito oceânico. Sepultados no fundo dos grandes abismos, eles nunca seriam encontrados. O novo leito oceânico, quando exposto à superfície, tornou-se a moderna topografia terrestre, o que explicava a exposição de rochas marinhas e fósseis acima do nível do mar.

De Luc argumentou que alguns animais sobreviveram em alguns topos montanhosos isolados antes que as águas do Dilúvio recuassem para as profundas cavidades originadas pelo colapso dos continentes. Junto com os animais libertos da Arca, estes sobreviventes repovoaram o mundo. $\mathrm{O}$ Dilúvio alterou o centro de gravidade do planeta de modo que ele se inclinou, dando origem às estações do ano e impondo a atual zonação climática do planeta. Uma vez que nada disso havia sido escrito na Bíblia, de Luc sustentou que tendo somente Moisés escrito sobre parte do Dilúvio testemunhado por Noé, as rochas completariam a história.

A difundida crença de que a história da natureza revelada por meio da ciência dava provas de um Deus benevolente foi forte na influente obra de William Paley chamada Teologia Natural - Natural Theology - (Paley 1802). Ele adotou o ponto de vista de Tomás de Aquino que afirmava que a Bíblia e o livro da natureza compartilhavam a mesma autoria. E que as revelações científicas que contradiziam as interpretações bíblicas deveriam levar a uma melhor interpretação das escrituras sagradas. $\mathrm{O}$ papa Pio VII logo reforçou a visão de que os seis dias da Criação foram muito mais longos do que uma semana com dias de vinte e quatro horas. Uma década após a publicação do popular livro de Paley, Robert Bakewell tentou reconciliar as cronologias bíblica e geológica na sua Introdução à Geologia (Bakewell 1813), o primeiro livro didático de geologia publicado em inglês. Ele argumentou que a cronologia descrita no Gênesis começou quando o mundo se tornou habitado pelo homem.

Os discípulos de Paley acreditaram que as evidências geológicas demandaram uma catástrofe de proporções bíblicas. Sumarizando tais ideias na obra O Testemunho da Teologia Natural para a Cristandade - The Testimony of Natural Theology to Christianity (Gisborne 1818), Thomas Gisborne sustentou que a necessidade de uma grande catástrofe na história da Terra era verificada na narrativa bíblica. Os estratos superficiais foram quebrados e deslocados por todos os lugares onde se podia verificá-los. As rochas das formações secundárias - aquelas depositadas em camadas horizontalizadas - apareciam quebradas e distorcidas onde quer que existisse alguma "janela" na estrutura interna da crosta. Assim, ele concluiu que a superfície da Terra mostrava marcas seguras de uma grande catástrofe passada.

Gisborne também afirmou posteriormente que os vales foram escavados pelo fluxo das águas. E que todos os rios drenavam para o nível dos oceanos o que comprovava que o relevo foi escavado pelas águas correntes que escoavam dos continentes para os oceanos ao invés de ter sido originado pelas correntes no fundo de um oceano primordial. Afirmou também que somente um terço do globo era composto por terra seca e que somente uma fração deste terço era responsável por espaços habitáveis às civilizações. Com isso demonstrava que a Terra não era nada além de uma ruína daquilo que um Deus sapiente e benevolente produzira. Finalmente, se o mundo ainda estivesse em um estado de inocência, ele não estaria sujeito a erupções vulcânicas e terremotos. A Terra em seu estado paradisíaco original fora destroçada e arrasada. Certamente algo grande deveria ter remodelado sua superfície.

\section{Muitas inundações}

As descobertas do final do século XVIII acerca das extinções e as numerosas evidências de campo interpretadas como registros de grandes catástrofes terminaram por tornar obsoleta a teoria do Dilúvio como responsável pela formação das camadas rochosas sedimentares. Quando o exército napoleônico retornou do território que hoje é a Bélgica com os artefatos roubados das coleções de história natural, o anatomista francês George Cuvier comparou os dentes de um mamute aos molares dos elefantes modernos da Ásia e África. Os dentes do mamute não se comparavam a nenhuma espécie viva. Os mamutes não mais caminhavam pelo mundo. A descoberta de extinções por Cuvier colocava uma pedra sobre a ideia do Dilúvio, já que tais extinções não poderiam coexistir com a ideia de um dilúvio em que cada casal de animais viventes havia sido salvo por meio de uma arca. 
Por meio do mapeamento das rochas da bacia de Paris, Cuvier descobriu que diferentes camadas sedimentares possuíam diferentes faunas fósseis. E que a diferentes períodos na história da Terra correspondiam diferentes conjuntos de plantas e animais. A fauna em cada formação parecia ter se desenvolvido durante certo tempo antes de ser substituída, substituição marcada pela camada de rocha sobrejacente. De acordo com suas ideias, uma catástrofe recente ou antiga poderia desaparecer com toda uma fauna que seria substituída por outra inteiramente nova. Tal concepção se corporificava em um dilema teológico já que então muitos dilúvios ou muitas inundações catastróficas poderiam ser identificados.

A visão de Cuvier de que o registro geológico é marcado por períodos de estabilidade pontuados por catástrofes tornou-se conhecida como catastrofismo. Suas ideias dão conta de uma geologia com uma abundância de teorias carentes de fatos. Ele acreditava que a história da Terra só seria desvelada por meio da observação das rochas e fósseis que elas continham. Na sua perspectiva, grandes teorias deveriam emergir das observações de campo e não de conjecturas.

$\mathrm{Na}$ primeira metade do século dezenove, os matacões de rocha que revestiam as paisagens do norte da Europa foram considerados evidências persuasivas de uma inundação global. George Greenough [1778- 1855], o primeiro presidente da Sociedade Geológica de Londres, discutiu em seu Exame Crítico dos Primeiros Princípios da Geologia (Critical Examination of the First Principles of Geology) (Greenough 1819) que uma vez que não se poderia considerar como regra a ação normal dos rios e do mar em mover grandes blocos rochosos, de fato, uma grande inundação deve ter movido tais matacões para os terrenos onde são encontrados. Greenough também afirmou que o Dilúvio afetou toda a Europa, tendo se baseado para isso nos largos depósitos de areias e cascalhos, tomados como representativos do último grande evento geológico acontecido. Embora Greenough pensasse que poderia afirmar sobre a direção do fluxo dessa inundação a partir da orientação das montanhas e vales, ele não encontrou evidências que revelassem quando isso havia acontecido. Quanto à causa desse evento, ele se conformou com a ideia de Edmund Halley de que um cometa ou meteoro, passando próximo à Terra ou mesmo colidindo com o planeta, seria capaz de causar tal fenômeno.

Menos de uma década e meia depois, Gree- nough retirou sua afirmação sobre a existência de um dilúvio em uma carta endereçada à Sociedade Geológica.

Há quatorze anos atrás, eu emiti uma opinião, fundada em considerações de caráter físico e geológico, de que a terra inteira foi, em um tempo desconhecido... recoberta pelas águas de um dilúvio. Essa opinião não foi rapidamente formada. Meu raciocínio foi baseado nos fatos que eu tinha até então. Minhas relações com a natureza física e geológica estão agora estendidas; e quanto maiores esses conhecimentos maior a necessidade de retificar-me. Novos dados são arrolados e com a franqueza dos meus predecessores leio agora esta minha retratação (Greenough 1834 p.69).

Após décadas de estudo de novas evidências, Greenough viu que os fósseis outrora atribuídos ao dilúvio foram depositados em múltiplos eventos, assim como o foram os matacões espalhados pela Europa.

A mais famosa retratação de opinião foi a do reverendo William Buckland, primeiro professor de geologia de Oxford. Em sua aula inaugural de 1819, Buckland afirmou que o registro geológico era condizente com o Dilúvio. Vários anos depois, ele apregoou a descoberta de lama e ossos preenchendo uma caverna perto de Kirkdale como confirmação de uma inundação cataclísmica. Mas após décadas de estudos de campo pela Inglaterra e Europa, Buckland concluiu que não existia qualquer marca geológica ou geomorfológica do dilúvio bíblico (Buckland 1836). Em seu famoso Bridgewater Treatise, ele reviu suas opiniões publicadas e compreendeu a existência de uma série de longas catástrofes geológicas.

As descobertas que têm sido feitas, desde a publicação deste trabalho, mostraram que muitos dos animais aí descritos existiram por mais de um período geológico, anteriores à catástrofe que os extirparam. É por isso mais adequado supor que o evento em questão foi o último de muitas revoluções geológicas produzidas por violentas irrupções de água e não a inundação tranquila descrita na Narrativa Inspiradora (Buckland 1836 v.I, p.95).

Por volta de 1830 tornou-se evidente que o Dilúvio ou uma inundação cataclísmica não poderia explicar o relevo nem as rochas da Europa. Aluno de Buckland, Charles Lyell lamentou todo o tempo perdido tentando ajustar as evidências de campo 
ao dilúvio bíblico. A atribuição dos fenômenos geológicos e geomorfológicos a tal evento impediu durante muito tempo o progresso no entendimento do mundo.

Nunca antes, em qualquer ramo da ciência, uma falácia teórica interferiu tão seriamente na acurácia da observação e classificação sistemática dos fatos (Lyell 1830, v.1, p.29-30).

Lyell defendeu a visão de Hutton de que o trabalho gradual dos processos geológicos e geomorfológicos poderia ser observado em ação nos dias atuais. Essa perspectiva tornou-se o fundamento do uniformitarismo.

Lyell acreditava que as ondas e correntes moldaram a topografia em um passado quando o nível do mar se encontrava mais alto que o atual. Esta teoria de erosão marinha se tornou muito popular quando não havia mais como sustentar a teoria diluviana. A ação contínua das ondas moldou as regiões costeiras. Em meados do século, muitos geólogos afirmavam que as colinas e vales tinham sido escavados abaixo do nível do mar. Somente em 1860 é que os defensores da desnudação marinha cederam à crença no poder dos rios em escavar os vales.

Os argumentos do século XIX entre catastrofistas e uniformitaristas centraram-se nas interpretações das evidências de campo e na capacidade dos processos graduais atualmente vigentes em modelar as paisagens modernas. Ao longo do século as duas correntes gradualmente convergiram na medida em que o número de dilúvios que os catastrofistas precisavam para explicar as evidências de campo aumentou.Por meio século houve um consenso entre geólogos que asseguravam que o dilúvio não poderia ter depositado todas as camadas de rochas sedimentares existentes, modelado o relevo terrestre nem depositado todas as acumulações de cascalhos, areias e matacões.

Nenhuma das correntes importantes da geologia acreditava mais em uma inundação global ou no Dilúvio. Nem mesmo as principais correntes teológicas. Mas ainda permanecia a questão sobre que força foi capaz de depositar os grandes matacões no norte da Europa.

Se você estiver muito seguro da resposta certa a uma determinada questão antes de analisá-la adequadamente, você estará mais inclinado a encontrar evidências que a suportem. As expectativas colorem as percepções. Isto foi verdade quando os extensivos níveis de cascalhos pela Europa foram interpretados como produtos do Dilúvio. Mas novos dados ou a mudança na perspectiva de análise tornou confusa a história pretérita. E o reconhecimento do naturalista suíço Louis Agassiz de que glaciações alteraram radicalmente a face da Europa acabaram com a ideia do Dilúvio (Agassiz 1840). A teoria glacial de Agassiz foi baseada em observações de campo que o levaram a propor uma Idade do Gelo.

Charles Darwin mais tarde relembrou de um fóssil encontrado numa expedição quando ele tinha deixado passar completamente despercebida a evidência de uma glaciação nas montanhas Welsh (Macdougall 2004). É fácil deixar algo passar quando não se olha na sua direção.

Quão fáceis podem ser ignorados os fenômenos, embora conspícuos, antes de serem observados por alguém ... nenhum de nós viu o maravilhoso vestígio do fenômeno glacial que nos cercava; nós não observamos as marcas nas rochas, os matacões, as morainas laterais e terminais (Macdougall 2004, p.16).

Nenhuma analogia óbvia existiu para os lençóis de gelo antes daqueles conhecidos na Groenlândia e na Antártida. Até então, a ideia de antigos lençóis de gelo parecia estranha para lugares a centenas de milhas do glaciar mais próximo. Sem uma teoria que se ajustasse às evidências, os geólogos subestimaram o significado das formas que posteriormente produziram uma demonstração convincente de antigas glaciações.

No ano em que Louis Agassiz apresentou sua teoria glacial, John Pey Smith [1774- 1851], reitor do London's Homerton Divinity College, ofereceu o que imaginou ser uma nova sugestão de como o Dilúvio afetara certas áreas e destruíra a antiga Terra dos homens em sua obra intitulada Sobre a Relação entre a Escritura Sagrada e Algumas Partes da Ciência Geológica (1840). Seguindo a tradição de Santo Tomás de Aquino, Smith afirmou que as revelações geológicas eram verdades fundamentais, comparáveis às verdades bíblicas. Smith não duvidara da veracidade histórica do Dilúvio e afirmou que muitas nações tiveram suas narrativas diluvianas. Apesar de tudo, o que realmente fora certo é que o Dilúvio afetou todas as nações existentes e destruiu o lar de toda a humanidade ancestral.

Smith rejeitou, no entanto, uma ação violenta das águas diluvianas. Ao contrário, ele propôs que uma lenta inundação destruiu a humanidade em 
algum lugar da Ásia Central, agora abaixo do nível do mar, como é o caso do Mar Cáspio. Smith lembrou aos seus leitores que as evidências geológicas poderiam ser usadas para ajudar na interpretação do Gênesis. Assegurando que qualquer discrepância entre a geologia e as Escrituras desapareceria mediante um cuidadoso e sincero exame, ele conclamou à reinterpretação da Bíblia quando as interpretações se mostraram conflituosas com as evidências geológicas (Smith 1840, p.20).

Smith sustentou as atordoantes controvérsias entre Buckland e Greenough como demonstrações contundentes da força das evidências geológicas. Ele acreditou que as evidências de campo capazes de motivar tais homens a abandonar suas convicções devem ter sido genuinamente convincentes.

Os anais de ciência, a literatura ou a teologia não apresentam uma instância mais nobre de imparcialidade e integridade, do que aquela mostrada pelos ... geólogos ... em ceder à opinião favorita, a qual eles também se filiaram em público de muitas maneiras, e pela qual eles foram aclamados com aplausos; sabendo também, de antemão, que cedendo ao poder das evidências, a confissão de uma honesta convicção os exporia à censura de alguns que, não entendendo nem o que diziam e nem porque o diziam, embora falassem e escrevessem com a confidência direta da sua incompetência em afirmar com convicção (Smith 1848 p.88-89).

Smith descreveu como os geólogos pensaram que o dilúvio fora um evento único, uma conclusão que suportou a ideia de uma inundação global. Mas o posterior exame dos minerais em seus depósitos revelou múltiplas fontes. Em alguns locais os sedimentos haviam vindo das proximidades, em outros eles pareciam ter vindo de montanhas distantes. Depósitos de várias idades foram encontrados, com sedimentos antigos enterrados por sedimentos mais recentes. A ideia de que uma única grande inundação havia depositado todos esses sedimentos era incondizente com as evidências de campo.

Smith relutantemente descreveu as ideias daqueles que insistiram na fragmentação da superfície terrestre pela ação do Dilúvio como premeditada para iludir as pessoas (Smith 1848, p.152).

As distintas pessoas que se opõem ao que a maior parte dos geólogos diz, ... levam em conta um fascinante livro, seja do professor Buckland, talvez, ou os Princípios do Sr. Lyell; ou, mais provavelmente, elas se contentam com algum autor mais antigo cujas afirmações nem sempre são as mais fiáveis. A partir disso, elas selecionam algumas afirmações, em decorrência das quais, pela sua falta de conhecimento, ficam expostas a uma compreensão errônea. Do grande número de fatos que deveriam ser conhecidos, muitos são ignorados e muitos esquecidos; e entre estes estão alguns que acabam por ... minar as concepções levantadas pelos compiladores. ... No final, tais pessoas se surpreendem e se irritam pelo fato de que os geólogos não adotam suas concepções (Smith 1848, p.151).

Em ataque aos trabalhos dos chamados geólogos bíblicos, Smith percebeu como eles geralmente propuseram ideias com pouco respeito às evidências de campo acumuladas pelas gerações de geólogos e filósofos naturais anteriores.

Granville Penn, um assistente no Departamento de Guerra britânico, descendente de William Penn (fundador do estado da Pensilvânia), afirmou que o mundo foi criado literalmente em seis dias há cerca de 6000 anos atrás. A obra na qual apresentou essas ideias foi intitulada Comparative Estimate of the Mineral and Mosaical Geologies (1822). Na sua concepção, Cuvier estava enganado sobre todas aquelas revoluções na história da Terra; somente duas ocorreram. Na Criação Deus deprimiu algumas áreas para abrigar os mares e então, 1656 anos depois ele mudou as coisas, elevando os oceanos e rebaixando os continentes, desencadeando o Dilúvio e destruindo tudo e todos que não estavam a bordo da Arca de Noé. Penn afirmou que suas ideias estavam baseadas em uma combinação do livro do Gênesis e da física newtoniana e levavam à verdade plena.

Apesar desse curioso sinal de autoridade científica, Penn invocou a sabedoria divina como argumento que se sobrepunha às problemáticas evidências de campo. As rochas foram feitas em correspondência com as leis que Ele estabelecera, e a aparência que adquiriram depois foi produzida somente graças àquelas leis (Penn 1822, p.77). Não haveria possibilidade de entender a história geológica como resultante de eventos atuais e em operação se as rochas representavam apenas os processos pretéritos. Penn admitia que as evidências de campo na compreensão da história da Terra eram nada mais que futilidades.

Embora tenha promovido uma interpretação literal da Bíblia, Penn não insistiu em uma inter- 
pretação literal de todos os aspectos da história do Dilúvio. A Arca de Noé não havia carregado um casal de cada animal da Terra. Os mamutes, por exemplo, foram extintos como parte do plano de Deus, mesmo porque não eram mencionados na Bíblia. E, tendo em conta que nenhuma vegetação poderia ter sobrevivido a um evento de inundação tão longo, Deus deve ter recriado muitas plantas depois do Dilúvio. Penn também tinha uma resposta ao porquê os rios ainda podiam ser reconhecidos em seus leitos após o Dilúvio. Ele considerou essa passagem problemática como uma inserção no livro do Gênesis depois de Moisés tê-lo escrito e, por isso, algo que não havia sido corretamente entendido sobre o Dilúvio. Ironicamente, ao defender uma interpretação literal da Bíblia, Penn introduziu interpretações não literais, adicionou milagres extras não mencionados e negligenciou algumas passagens.

Outro influente geólogo autodidata que seguiu fielmente as ideias contidas na Bíblia foi George Fairholme. Ele defendeu a ação incisiva do Dilúvio em termos geológicos e geomorfológicos em suas Novas e Conclusivas Demonstrações Físicas dos Fatos e Tempos do Dilúvio - New and Conclusives Demonstrations Both of the Face and Period of the Mosaic Deluge (Fairholme 1837). Ignorando entre outras evidências os já conhecidos problemas apresentados pelas rupturas no registro geológico (tal como a inconformidade de Hutton) e as evidentes seções de camadas com acentuados mergulhos espalhadas por toda a Europa, Fairholme argumentou que as rochas sedimentares eram muito jovens $\mathrm{e}$ que haviam se formado rapidamente. Além disso, ele sustentou que simplesmente não poderia ter havido grandes perturbações da Terra antes do Dilúvio. Se essas tais forças perturbadoras da ordem do mundo fossem resultantes do pecado, como poderiam ter ocorrido antes do advento dos pecadores?

Fairholme afirmou que os geólogos que sustentavam mais de uma grande catástrofe negavam a autenticidade e verdade da Bíblia. Porque Deus teria enviado grandes enchentes para repetidamente destruir o mundo, antes que a humanidade existisse, se o Dilúvio foi justamente para punir a maldade humana sobre a Terra? Reutilizando ideias descartadas, os geólogos das escrituras ignoraram ou cavalheirescamente negligenciaram as descobertas de Hutton, Cuvier, Buckland e Lyell. Por outro lado nenhum geólogo de campo deu a eles qualquer crédito.

\section{0 testemunho das rochas}

Cada vez mais, os teólogos do século dezenove concluíam que quando as evidências de campo entravam em conflito com as interpretações bíblicas, estas últimas é que deveriam se adaptar àquelas evidências. Muitos geólogos influentes, dos dois lados do Atlântico, sustentaram a ideia de que as investigações científicas poderiam ajudar a construir interpretações mais esclarecidas dos textos bíblicos. O principal consenso teológico e científico foi o de que as evidências de campo deveriam ser analisadas em seus méritos, de modo a que as teorias geológicas e a interpretação bíblica não fossem discordantes.

$\mathrm{Na}$ América do Norte, Edward Hitchcock [1793-1864] contribuiu para a ideologia do Dilúvio. Proeminente membro da Academia Nacional de Ciências, presidente do Amherst College, professor de Geologia e teólogo calvinista, Hitchcock assegurou que tudo aquilo que fosse descoberto pela geologia poderia ... ser confirmado pela Bíblia, de modo que não haveria nenhuma contradição entre esses dois relatos da natureza (Young 1995, p.141). De maneira pouco usual para um geólogo de sua época, ele escreveu para periódicos teológicos e eclesiásticos argumentando que a geologia poderia ajudar nas interpretações conflituosas do relato bíblico sobre a Criação e o Dilúvio.

Hitchcock defendeu seu ponto de vista em um extenso artigo de três partes no The American Biblical Repository [Hitchcock 1837-1838]. Na primeira parte, ele revisou as várias histórias sobre a grande inundação que cobriu a Terra e afirmou que existiam muitas similaridades entre elas. $\mathrm{Na}$ segunda, ele revisou a história das ideias e evidências geológicas sobre o Dilúvio. Embora entendesse que os filósofos naturais dos séculos XVII e XVIII aceitassem a ação geológica do Dilúvio, parecia um mistério para ele como qualquer um ainda poderia sustentar que o relevo e o registro fóssil fossem produtos de uma inundação global baseado em trabalhos ultrapassados como aqueles de Burnet e Woodward. Hitchcock acusou os geólogos bíblicos de distorcer tanto as Escrituras quanto a geologia.

Mais do que tudo, Hitchcock afirmou que as rochas secundárias foram originadas no intervalo entre a Criação e o Dilúvio e que os estratos terciários foram depositados pelo Dilúvio. Tais ideias já haviam sido descartadas. Quanto mais profunda a investigação em uma camada, maiores as diferenças entre os fósseis aí encontrados e a fauna moder- 
na. E o único modo de atribuir a preponderância de criaturas extintas no registro fóssil relativo ao Dilúvio era invocar uma segunda etapa de criação envolvendo novas espécies - algo que tornaria o papel da arca desnecessário.

$\mathrm{Na}$ terceira parte do seu artigo, Hitchcock tratou da veracidade da narrativa mosaica sobre o Dilúvio. Após rever os maiores problemas com a aceitação da narrativa bíblica, ele admitiu um dilúvio não global, tendo em vista as contradições advindas de uma simples leitura das escrituras sagradas. Além do mais, era preciso harmonizar as interpretações bíblicas com a natureza.

Posteriormente, ele comentou a respeito do Dilúvio em sua Religião da Geologia - Religion of Geology-(1852).

A história das opiniões a respeito do Dilúvio é uma das mais curiosas e instrutivas na história da humanidade. ... Esta é uma questão da qual os homens se supõem mestres, quando na verdade são apenas entendedores superficiais do assunto. Quase todas as mudanças geológicas pelas quais a terra passou, do seu centro às suas camadas mais superficiais, têm sido atribuídas ao dilúvio. E tão lógica tem parecido tal questão a eles que nada mais têm do que uma visão parcial dos fatos. Mas muitas dessas opiniões e do seu dogmatismo estão agora abandonados, porque tanto a Natureza quando as Escrituras são agora melhor compreendidas (Hitchcock 1852, p.112).

Hitchcock sustentou um dilúvio não global porque era claro que a Idade do Gelo de Agassiz explicava muitas das evidências geológicas atribuídas anteriormente ao Dilúvio. Assim, Hitchcock endossou a ideia de Lyell de que a inundação da bacia do Mar Cáspio afogara o antigo lar da humanidade.

Do outro lado do Atlântico, Hugh Miller [1802-1856] popularizou tal visão. Miller, em sua juventude, ficou intrigado pelos fósseis de peixe que ocasionalmente apareciam nas rochas onde ele trabalhava. Estudando-os nas pedreiras ao longo da costa escocesa, ele construiu uma grata reputação como um geólogo sério, após publicar a obra The Old Red Sandstone (Miller 1841). Como um devotado presbiteriano que editou a primeira publicação do Evangelho da Igreja da Escócia, as compreensões geológica e teológica de Miller convenceram-no de que as rochas não representavam nenhuma ameaça ao cristianismo. Um prolífico escritor de livros populares com o dom da clara expressão, Miller tornou-se uma voz ativa entre aqueles que procuravam harmonizar a interpretação da Bíblia com os registros geológicos.

Miller acreditou que todas as narrativas diluvianas se referiram a uma antiga inundação, mas rejeitou a ideia de que fosse uma inundação planetária. Na sua perspectiva, não havia necessidade de desconsiderar as evidências geológicas mesmo não compreendendo com exatidão o que teria acontecido. Presos na arca, Noé e os seus não teriam tido condições de saber a extensão do Dilúvio. E todo o resto da humanidade havia morrido. Talvez Deus pudesse ter refeito tudo diferente. Mas a Bíblia foi escrita com propósitos morais e não científicos. Miller se preveniu da tarefa exagerada de discernir, a partir da Bíblia, os fatos geográficos, geológicos e astronômicos. Uma leitura literal poderia levar aos mesmos excessos cometidos por aqueles que haviam situado Jerusalém no centro do universo.

Miller argumentou que à Bíblia convinha o que era a sua missão - ensinar sobre a salvação espiritual - mas o tempo e quando tais acontecimentos ocorreram não era sua intenção revelar; as verdades da ciência física, - todas elas caíram em erros extravagantes (Miller 1866, p.306). Afirmando que os avanços científicos iluminariam a interpretação bíblica, ele se resguardou da ignorância daqueles que desejaram resolver os problemas da ciência com as palavras da bíblia.

Miller notou que por meio século nenhum paleontólogo ou geólogo acreditou que as rochas apresentassem evidências de uma inundação global. Aqueles que procuraram por evidências do Dilúvio voltaram-se para os depósitos superficiais - até que mesmo estes se provaram infrutíferos em termos de comprovação. Adotando a solução de Lyell para o quebra-cabeças do Dilúvio, Miller argumentou a favor de uma inundação na Ásia Central cujo resultado seria o Mar Cáspio ou o Mar de Aral. Dando-se conta da salina costa salgada do Mar Cáspio e de suas conchas parecia evidente que sua extensão deveria ter sido bem maior no passado. Isso o levou a concluir que teria acontecido ali uma grande enchente que submergira completamente a região.

Hitchcock e Miller foram devotados cristãos, e muito bem versados na teologia tradicional. Eles entenderam as evidências geológicas que se contrapunham à concepção tradicional do Dilúvio não como uma ameaça à sua fé mas como uma oportunidade para melhor compreender o livro do Gênesis. Com suas ortodoxas credenciais teológicas, 
eles se empenharam profundamente em encontrar a verdade a partir da natureza e das escrituras sagradas. Paralelamente às correntes tradicionais da teologia, eles adaptaram a leitura do Gênesis de acordo com as descobertas geológicas.

Por volta de 1860, nenhum geólogo acreditava mais no Dilúvio. O escocês Archibald Geikie descreveu a situação como um debate encerrado.

No presente momento parece supérfluo ressuscitar os fantasmas de antigos dilúvios e desastres, os quais, após terem sido matéria de grande interesse nos primórdios da história da geologia, têm agora sido consignados ao esquecimento. Poucos ainda sustentam a crença, de que os fenômenos da Deriva são devidos a um dilúvio cataclísmico (Geikie 1863, p.73).

Todavia, nessa época, poucos ainda eram os cristãos que acreditavam viver em um planeta não muito mais velho que as pirâmides. $\mathrm{O}$ reverendo Richard Main sumarizou a perspectiva anglicana conservadora: Alguns livros didáticos ainda ensinam que a Terra tem 6000 anos de idade. ... Nenhuma pessoa bem educada dos dias atuais compartilha esta desilusão (Roberts 2007, p.39). Embora as velhas concepções sobre o Dilúvio ainda tenham sido perseguidas obstinadamente por aqueles que defendiam uma autoridade literal da Bíblia, tais vozes se tornaram marginais quando se tornou convencional entre teólogos e geólogos a ideia de grandes inundações regionais.

Quando a geomorfologia ganhou o reconhecimento de disciplina distinta, após o Congresso Geológico Internacional de 1891, a visão do Dilúvio era a de um fenômeno regional, largamente aceito por cristãos escolarizados em todo o mundo. A teoria diluviana afundou sob o peso dos vários indícios geológicos e geomorfológicos que evidenciavam uma longa, complicada e espacialmente diversa história dos processos de esculturação e evolução da paisagem.

\section{Campo e teoria hoje}

As observações de campo moldaram e remoldaram a teoria geológica e geomorfológica (bem como a teologia) na medida em que a pesquisa por evidências sobre o Dilúvio moveu-se do colapso completo da crosta terrestre para a formação de rochas sedimentares fossilíferas antes de, finalmente, rumar para o estudo dos depósitos superficiais e morfológicos. Eventualmente, o peso das evidências de campo levou ao abandono de uma influente teoria vigente sobre uma grande inundação global, fosse essa o dilúvio bíblico ou não. Atualmente, a relação entre as observações de campo e as teorias é algo extremamente pertinente como o foi durante séculos de debate sobre o Dilúvio - por isso ainda se pode dizer que as expectativas dão o tom às percepções.

A produtiva tensão entre campo e teoria moldou avanços do século XX tais como o desenvolvimento da tectônica de placas, o reconhecimento de inundações de grande magnitude e os esforços de modelizar a evolução da paisagem. Hoje, uniformitarismo e catastrofismo não são mais ideias diametralmente opostas. Elas consistem em estruturas conceituais complementares ao entendimento da história de paisagens específicas. Enquanto a experiência de J Harlen Bretz produziu um bem conhecido exemplo do valor das evidências de campo na avaliação de teorias, o campo, que é um ponto básico para qualquer geomorfólogo de campo ou teórico, permanece essencial.

A lição histórica é tão simples quanto óbvia. A crença na teoria não deve nunca sobrepujar os dados e as evidências de campo só fazem sentido se interpretadas com a ajuda de uma teoria razoável. O diálogo entre teoria e campo ajuda a alavancar a compreensão de como as teorias servem e serviram à geomorfologia. A recente difusão de recursos computacionais e o resultante salto na habilidade de simular e modelar os processos geomorfológicos e a evolução da paisagem trouxeram à tona alguns aspectos teóricos da geomorfologia, já bem estabelecidos, que ameaçam ofuscar escassos dados de campo. Por outro lado, a abundância de dados topográficos detalhados, por exemplo aqueles associados à tecnologia LIDAR, abre portas para novas teorias. O que é certo, todavia, é que o diálogo entre campo e teoria produz a tensão necessária ao avanço do pensamento geomorfológico, e é tão essencial hoje quanto foi no passado.

\section{Referências}

Agassiz L. 1840. Études sur les Glaciers Jent et Gassmann, Neuchatel.

Agostinho Santo. 1982. The Literal Meaning of Genesis. Trad. por J.H. Taylor, New York, Newman Press. Agricola G. 1912 (1556). De Re Metallica. Trad. por H.C. Hoover e L.H.Hoover, , London The Mining Magazine, Salisbury House.

Bakewell R. 1813. An Introduction to Geology. J. Har- 
ding, London.

Bates M1950. . The Nature of Natural History. Charles Scribner's Sons, New York.

Bellers F. A description of the several strata of earth, stone, coal, etc. found in a coal-pit at the west end of Dudley in Staffordshire. Philosophical Transactions of the Royal Society of London 27, 541-544. 1710.

Buckland W. 1836. Geology and Mineralogy, Considered with Reference to Natural Theology. William Pickering, London.

Buffon. Histoire Naturelle, Generale et Particuliere, Avec la Description du Cabinet du Roy, Tome Premier. De L'imprimerie Royale, Paris. 1749.

Buffon. Les Époques de la Nature. De L'imprimerie Royale, Paris. 1778.

Burnet T. 1684. The Theory of the Earth: Containing an Account of the Original of the Earth and of All the General Changes Which it Hath Already Undergone, or is to Undergo, Till the Consumation of All Things, The Two First Books Concerning the Deluge, and Concerning Paradise. Printed by R. Norton, for Walter Kettilby, at the Bishops-Head in St. Paul's Church-Yard.

Catcott A. Treatise on the Deluge. London. 1761.

Chorley R.J., Dunne A.J., Beckinsale R.P. The History of the Study of Landforms or the Development of Geomorphology, Volume One: Geomorphology Before Davis. Methuen \& Co Ltd and John Wiley \& Sons Inc., Frome and London.

Cohn N. 1996. Noah's Flood: The Genesis Story in Western Thought. Yale University Press, New Haven and London.

Cutler A. 2003. The Seashell on the Mountaintop. Dutton, New York. 1964.

Davies G.L. 1969. The Earth in Decay: A History of British Geomorphology 1578 to 1878. New York, American Elsevier Publishing Co.

De Luc J.-A. 1831 (1798). Letters on the Physical History of the Earth Addressed to Professor Blumenbach Containing Geological and Historical Proofs of the Divine Mission of Moses. London, Printed for C.J.G. and F. Rivington.

De Maillet B. 1797 (1748).Telliamed; or, the World Explain'd: Containing Discourses Between an Indian Philosopher and a Missionary, on the Diminution of the Sea - the Origin of Men \& Animals: And Other Singular Subjects, Relating to Natural History \& Philosophy. Baltimore, MD. Printed by W. Pechin, No. 15 Market-Street-for D. Porter, at the Observatory, Federal-Hill.

Fairholme G. 1837. New and Conclusive Physical Demonstration Both of the Fact and Period of the Mosaic Deluge, and of its Having Been the Only Event of the Kind That has Ever Occurred Upon the Earth. London, James Ridgway \& Sons.

Geikie A. 1863.On the Phenomena of the Glacial
Drift of Scotland. Transactions of the Geological Society of Glasgow, v. 1, pp. 1-190. part II.

Gisborne T. 1818. The Testimony of Natural Theology to Christianity. Philadelphia, PA, M. Thomas.

Goeree W. 1690. Joodse Oudheden (Jewish Antiquities), Amsterdam.

Greenough G.B. 1834. Address delivered at the anniversary meeting of the Geological Society on the 21st of February 1834. Proceedings of the Geological Society of London, 2(35):42-70.

Greenough G.B. 1819. A Critical Examination of the First Principles of Geology. London, Longman, Hurst, Rees, Orme, and Brown. 1690.

Hitchcock E. 1837-8. The historical and geological deluges compared. The American Biblical Repository, 9:78-139; 10:328-373; 11:1-27.

Hitchcock E. 1852. The Religion of Geology and its Connected Sciences. Boston, Phillips, Sampson, and Company.

Lyell C. 1830. Principles of Geology, Being an Attempt to Explain the Former Changes of the Earth's Surface by Reference to Causes Now in Operation. London, John Murray.

Macdougall D. 2004. Frozen Earth: The Once and Future Story of Ice Ages. Berkeley, Univ. California Press.

Mather K.F., Mason S.L. 1970. A Source Book in Geology, 1400-1900. Cambridge, MA, Harvard Univ. Press.

Mayor A. 2000. The First Fossil Hunters: Paleontology in Greek and Roman Times. Princeton, Princeton Univ. Press.

Miller H. 1841. The Old Red Sandstone. Edinburgh, Johnstone.

Miller H. 1866. The Testimony of the Rocks; or, Geology in its Bearings on the Two Theologies. Natural and Revealed. Boston, Gould and Lincoln.

Montgomery D.R. 2012. The Rocks Don't Lie: A Geologist Investigates Noah's Flood. W.W. Norton \& Co., New York.

Nicolson M.H. 1997. Mountain Gloom and Mountain Glory: The Development of the Aesthetics of the Infinite. Seattle and London, Univ. of Washington Press.(1959).

Paley W. 1802. Natural Theology: Or Evidences of the Existence and Attributes of the Deity, Collected From the Appearances of Nature. London, Printed for R. Faulder, New Bond- Street, by Wilks and Taylor, Chancery-Lane.

Penn G. 1822. A Comparative Estimate of the Mineral and Mosaical Geologies. London, Ogle, Duncan, and Co.

Raleigh W. 1628. The Historie of the World. London, Printed for H. Lownes, G. Lathum, and R. Young.

Roberts M.B. 2007. Genesis Chapter 1 and geological time from Hugo Grotius and Marin Mersenne to William Conybeare and Thomas Chalmers 
(1620-1825). In: Piccardi L., Masse W.B. (Eds.), 2007. Myth and Geology. London, Special Publ. 273. Geol. Society. pp. 39-49.

Scheuchzer J.J. 1731. Kupfer-Bibel in Welcher die Physica Sacra oder Geheiligte Natur-Wissenschaft (Sacred Physics). Augsburg and Ulm.

Smith J.P. 1840. On the Relation between the Holy Scriptures and Some Parts of Geological Science. New York, D. Appleton \& Co.

Smith J.P. 1848. The Relation Between The Holy Scriptures and Some Parts of Geological Science. Jackson and Walford, London.

Warren E. 1690. Geologia: Or, A Discourse Concerning the Earth Before the Deluge. London, Printed for R. Chitwell, at the Rose and Crown in St. Paul's Church-Yard.
White A.D. 1910. A History of the Warfare of Science with Theology in Christendom. New York, D. Appleton and Co.

Woodward J. 1723 (1695). An Essay Towards a Natural History of the Earth and Terrestrial Bodyes, Especialy Minerals: As Also of the Sea, Rivers, and Springs. With an Account of the Universal Deluge: And of the Effects that it had upon the Earth. Printed for A. Bettesworth and W. Taylor in Pater-noster Row, R. Gosling at the Middle-Temple-Gate in Fleet-Street, and J. Clarke under the Royal-Exchange in Cornhill.

Young D.A. 1995. The Biblical Flood: A Case Study of the Church's Response to Extrabiblical Evidence. Grand Rapids, MI, William B. Eerdmans Publ. Co.

RESUM0: As opiniões sobre a origem do relevo terrestre têm sido marcadas pela fronteira entre ciência e religião. A criação do mundo que conhecemos é central para as visões religiosas e seculares do mundo; e até recentemente o poder de moldar as paisagens foi além do alcance dos mortais, atraindo especulações como as relacionadas ao papel da intervenção divina. Por séculos, o pensamento racional cristão questionou-se sobre a origem da superfície terrestre levando em consideração o Dilúvio de Noé que deu origem a montanhas e vales. Somente quando os geólogos aprenderam como decifrar a história da Terra e os sinais dos processos que moldaram a topografia terrestre é que, de fato, os naturalistas alcançaram uma compreensão das forças que moldaram o mundo. Nesse sentido, as raízes históricas da geomorfologia encontram-se na tensão entre a fé nas teorias e o poder de persuasão das observações de campo - questões que permanecem importantes à prática geomorfológica hoje em dia.

PALAVRAS-CHAVE: História da geomorfologia, dilúvio, campo, teoria. 